Portland State University

PDXScholar

Spring 6-6-2019

\title{
Dynamics of Wet-Season Turbidity in Relations to Precipitation, Discharge, and Land Cover in Three Urbanizing Watersheds, Oregon
}

Junjie Chen

Portland State University

Follow this and additional works at: https://pdxscholar.library.pdx.edu/open_access_etds

Part of the Geography Commons

Let us know how access to this document benefits you.

Recommended Citation

Chen, Junjie, "Dynamics of Wet-Season Turbidity in Relations to Precipitation, Discharge, and Land Cover in Three Urbanizing Watersheds, Oregon" (2019). Dissertations and Theses. Paper 5118.

https://doi.org/10.15760/etd.6997

This Thesis is brought to you for free and open access. It has been accepted for inclusion in Dissertations and Theses by an authorized administrator of PDXScholar. Please contact us if we can make this document more accessible: pdxscholar@pdx.edu. 
Dynamics of Wet-Season Turbidity in Relations to Precipitation, Discharge, and Land Cover in Three Urbanizing Watersheds, Oregon

by

Junjie Chen

A thesis submitted in partial fulfillment of the requirements for the degree of

\author{
Master of Science \\ in \\ Geography
}

Thesis Committee:

Heejun Chang, Chair

Paul C. Loikith

Eugene Foster

Portland State University

2019 
(C) 2019 Junjie Chen 


\begin{abstract}
Frequent intense precipitation events can mobilize and carry sediment and pollutants into rivers, degrading water quality. However, how seasonal rainfall and land cover affect the complex relationship between discharge and turbidity in urban watersheds is still under investigation. Using hourly discharge, rainfall, and turbidity data collected from six stations in three adjacent watersheds between 2008 and 2017, we examined the temporal variability of the discharge-turbidity relationship along an urban-rural gradient. We quantified hysteresis between normalized discharge and turbidity by a Hysteresis Index (HI) and classified hysteresis loops during 377 storm events in early, mid, and late wet season. Hysteresis loop index and direction varied by site land cover type and season. Turbidity values peaked quicker in the watersheds with higher degrees of urban development than a less urbanized watershed. The positive relation between discharge and turbidity was highest in two downstream stations in the mid wet season, while it was highest in two upstream stations in the early wet season. Correlation and regression analysis showed that maximum turbidity was best explained by discharge range, and the sensitivity of turbidity to discharge change was higher in the larger downstream watershed than in the small upstream watersheds. A flashiness index was negatively associated with the slope of turbidity versus discharge, suggesting that turbidity is difficult to predict solely based on discharge in flashy urban streams. This paper contributes to a deeper understanding of the spatial and temporal variation of dischargeconcentration relationship in urbanizing watersheds, which can help water managers increase the resiliency of water-related ecosystem services to impacts of climate change.
\end{abstract}




\section{Acknowledgments}

Special thanks to my advisor Dr. Heejun Chang for his continuous support, insightful suggestions, and immense knowledge in assisting me with this research. Also, thanks to Dr. Paul Loikith and Dr. Eugene Foster for serving on my thesis committee and providing comments on research design and methods. I also thank the Clackamas Watershed Resilience project team for inspirations and suggestions throughout this research project. This research was supported by the Portland State University Institute for Sustainable Solutions and community partners from Clackamas County and Clackamas Water Providers. 


\section{Table of Contents}

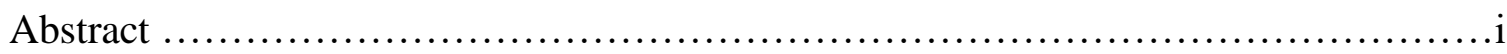

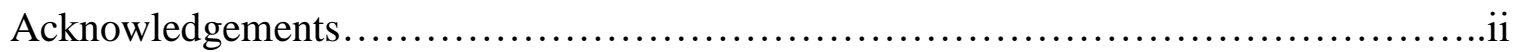

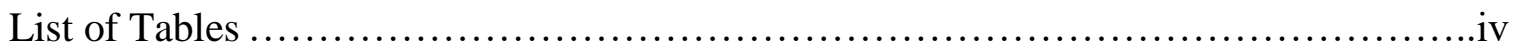

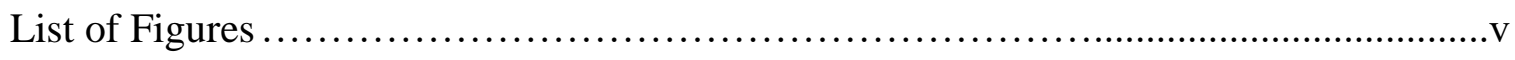

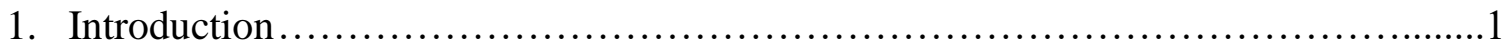

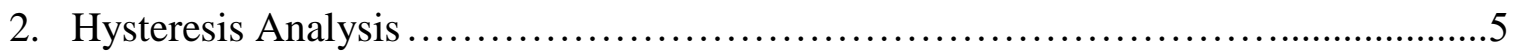

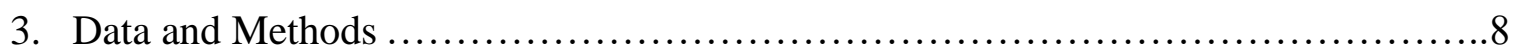

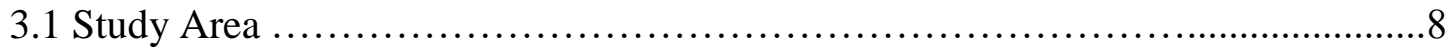

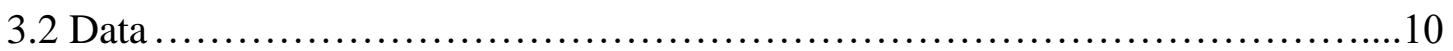

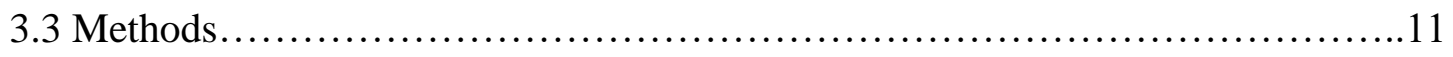

3.3.1 Storm Identification ............................................. 11

3.3.2 Hysteresis Models ................................................ 12

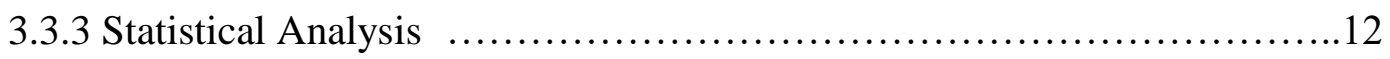

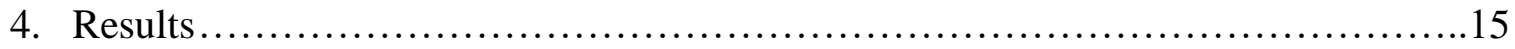

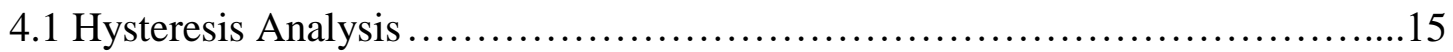

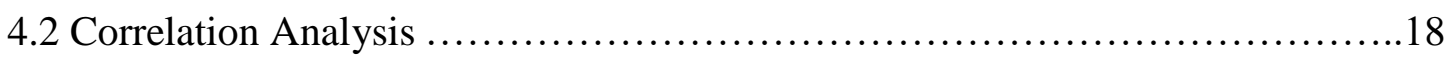

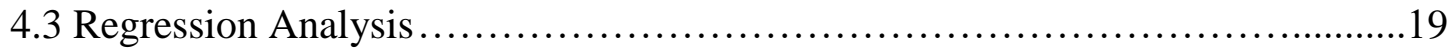

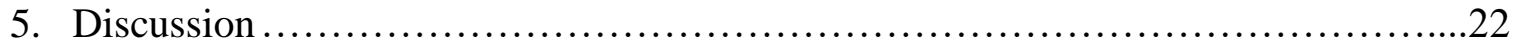

5.1 Hysteresis loop classification and patterns .................................22

5.2 Climate and seasonality on turbidity behaviors ..............................23

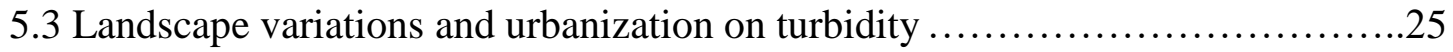

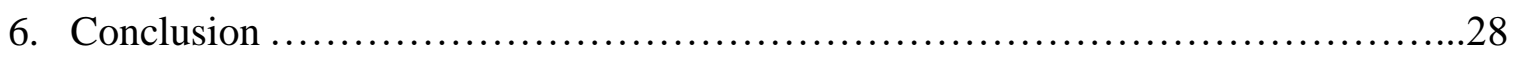

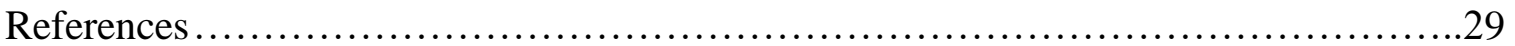

Appendix A. Literature review table .............................................. 34 


\section{List of Tables}

Table 1. Land and hydrological characteristics of stations in the study area

Table 2. Hysteresis loop classifications of identified storms from WY 2009-2017

Table 3. Spearman's rank correlation coefficients values by study sites and season 


\section{List of Figures}

Figure 1. Dominant hysteresis patterns explained

Figure 2. Map of study area land cover and monitoring sites

Figure 3. Hysteresis index by study site and season for all analyzed storms

Figure 4. Discharge range and turbidity maximum rating curves by nonlinear regression model at studied sites

Figure 5. Linear regression models of turbidity maximum and cumulative precipitation for study sites

Figure 6. Relation between flashiness index and slope of turbidity vs discharge 


\section{Introduction}

Anthropogenically induced climate change can cause shifts in temperature and precipitation patterns in the Pacific Northwest of the USA and around the globe. Climate projections indicate this regime shift can impact the amount and timing of water supply and water quality (Chang and Jones 2010; Jaeger et al. 2017). The Western-Cascade region in Oregon is estimated to be very sensitive to these changes as regional municipal and agricultural water use depends heavily on rain and snow accumulations from fall to spring (Cooley and Chang 2017). River systems in Oregon are primarily fed largely by precipitation during the wet season and groundwater and snowmelt during the dry seasons. These rivers such as the Clackamas River offer important water-related ecosystem services to irrigate crop fields, provide drinking water, and sustain aquatic habitat. Hydrological changes projected by downscaled climate models showed increasing winter discharge and earlier spring snowmelt runoff (Graves, David; Chang 2007; Jung, Moradkhani, and Chang 2012). These shifts in hydro-meteorological regimes can affect water quality by increasing the build-up of sediments in the drier seasons and transport of these sediments during extreme storms events (Tuset, Vericat, and Batalla 2016). Additionally, rapid land cover change in mixed land-use catchments contributes to riparian and near-channel soil erosion (Brasington and Richards 2000). In urbanizing watersheds, downstream water quality is more susceptible to degrade as stormwater runoff from impervious surfaces carries more pollutants into the rivers (Chen and Chang 2014). 
The complexity of sediment availability and transport depends mainly on both rainfall intensity and degrees of development in an urban watershed. Antecedent hydrological conditions and soil moisture level (Botter, Peratoner, Porporato, RodriguezIturbe, \& Rinaldo, 2007) both play an essential role in impacting the likelihood of soil erosion (Chang \& Carlson, 2005; Gray, Pasternack, Watson, Warrick, \& Goñi, 2015). A more significant portion of suspended sediment is mobilized during wet seasons when discharge values peak (Oliveira \& Quaresma, 2017). Seasonal precipitation variability and change can significantly influence the timing of extreme events, which can affect the discharge-concentration during storms. The discharge-concentration relationship was examined by previous studies (Foster, 1978; Moog \& Whiting, 1998; Walling \& Webb, 1980; Williams, 1989) to identify possible seasonal and land factors that contribute to the lag time between discharge peaks and water quality parameter peaks. Mather \& Johnson (2014) found that antecedent moisture conditions also affect turbidity on an event-byevent basis. Walling and Webb (1982)discovered that "first flush" sediment exhaustion effects characterize turbidity response and event scale flux patterns.

Turbidity is a crucial physical indicator of water quality, and it can act as a surrogate for suspended sediment concentrations, phosphorus, and organic matter. Turbidity values increase significantly during intense storms due to remobilization and resuspensions of bed sediments (Jiufa \& Chen, 1998) as well as newly eroded sediment from various sources in the watershed; it can also increase after small rain events following a prolonged dry period due to sediment build-up on topsoil, which if eroded, has a longer suspension time than subsoil (Resler, 2011). Elevated turbidity levels often increase water treatment cost (Dearmont, McCarl, \& Tolman, 1998); a deeper 
understanding of timing and cause of high turbidity levels during storms can reduce the societal value of diminished water quality. With the availability of high temporal resolution turbidity data that can monitor water quality every 30 minutes, researchers can now carefully examine short-term variations of discharge-turbidity relationships for individual storms events.

Heterogeneity of basin morphology can impact the source and distribution of sediment supply. Large and heterogeneous basins can exhibit substantial differences in land use and land cover, creating spatial variability of the discharge-turbidity relationship (Botter et al., 2007; Salvadore, Bronders, \& Batelaan, 2015) and impacting turbidity levels. On the other hand, for a watershed with homogenous characteristics such as land cover, soil type, and geology, metrological parameters and river hydrology will likely be the driving force of change in turbidity peaking timing and magnitude (Brasington \& Richards, 2000). In smaller watersheds, rainfall parameters are the primary drivers for hysteresis behaviors (Ram \& Terry, 2016). Furthermore, in-channel processes and energy exerted by high flows events that re-suspended riverbed sediments can also cause significant shifts in hysteresis patterns (Pietroń, Jarsjö, Romanchenko, \& Chalov, 2015).

Urbanization plays a significant role in influencing discharge-turbidity behaviors by having intricate distribution patterns of impervious surfaces (Peters, 2009). Unlike rural area, where land cover is mostly homogenous, urban landscapes are highly heterogeneous and therefore can affect the hydrological response at the watershed (Meierdiercks, Smith, Baeck, \& Miller, 2010). Natural and anthropogenic alteration of channel flow can influence infiltration, runoff ratio, and even groundwater recharge, 
impacting the water cycle at multiple spatial scales (Mainali, Chang, \& Chun, 2019). Furthermore, as natural pervious land covers are converted to impervious surfaces, compaction of soils could happen, which will all lead to a reduction of infiltration (McGrane, 2016). During intense precipitation events, rainfall runoff from paved roads, building rooftops, and drainage pipes can affect infiltration rates and the speed at which runoff enters the flowing channel of the river, and these effects can differ seasonally (Redfern, Macdonald, Kjeldsen, Miller, \& Reynard, 2016). As a result, urban area sediment erosion from results of flashy hydrography usually cause turbidity to peak before discharge. In contrast, rural areas with mostly vegetation and forest cover will exhibit less urban influence on the water balance cycle, making the sediment mobilization and transport process slower and more naturally spread out across the entire watershed, without many anthropogenic influences (Salvadore et al., 2015). 


\section{Hysteresis Analysis}

Hysteresis is very common in hydrology. Williams (1989) observed and classified different shapes of hysteresis loops between discharge and water quality parameters during a storm. Hysteresis can efficiently capture the time lag between two dependent variables in response to an independent variable. Typically, there exists a lag time difference between streamflow and turbidity, which can be quantified using a Hysteresis Index (HI). The relationship between discharge and turbidity can be examined visually using hysteresis loops (Lloyd, Freer, Johnes, \& Collins, 2016b; Zuecco, Penna, Borga, \& van Meerveld, 2016). Differences in hysteresis loop pattern and direction can be understood by the effects of weather, landscape, and stream channel connectivity. Hysteresis loop patterns can vary by loop direction and shape (Figure 1). Several hysteresis analyses were used to quantify the concentration-discharge relationship, and clockwise patterns are dominant in more urban watersheds while anticlockwise patterns are more common in rural watersheds, likely associated with whether the sources of sediment are near or distant and concentrated or distributed from streams. However, the application of hysteresis index using high-resolution data and applying for various watersheds that differs in size, climate, and land characteristics are still being researched. After examining past literature, we applied the methods by Zuecco et al. (2016) due to the robustness of their hysteresis index calculations on complex hysteresis patterns, applicability across watersheds at various spatial-temporal scales, and the open-source JavaScript code. 


\begin{tabular}{|c|c|c|c|c|}
\hline$\stackrel{\bullet}{\therefore} \quad \dot{\bullet}$ & $\bullet^{\bullet}$ & 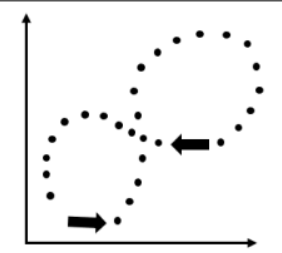 & 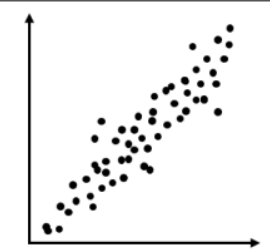 & 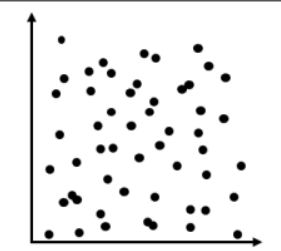 \\
\hline $\begin{array}{l}\text { Clockwise loop } \\
\text { direction, turbidity } \\
\text { values peaks before } \\
\text { discharge, sediment } \\
\text { sources could be near- } \\
\text { by. Large loop area } \\
\text { indicates longer lag } \\
\text { time, common in } \\
\text { urban watersheds }\end{array}$ & $\begin{array}{l}\text { Anti-clockwise loop } \\
\text { direction, turbidity } \\
\text { values peaks after } \\
\text { discharge peak, } \\
\text { possible delay in } \\
\text { sediment transport. } \\
\text { Smaller loop area } \\
\text { indicates shorter lag } \\
\text { time, common in well } \\
\text { preserved watersheds }\end{array}$ & $\begin{array}{l}\text { Figure-of-eight loop, } \\
\text { where loop direction } \\
\text { changes during the } \\
\text { middle of the elevated } \\
\text { hydrograph, indicates } \\
\text { possible exhaustion of } \\
\text { sediment after initial } \\
\text { flushing, not common }\end{array}$ & $\begin{array}{l}\text { Linear pattern, } \\
\text { indicates no visible } \\
\text { hysteresis pattern or } \\
\text { lag between turbidity } \\
\text { peaks and discharge } \\
\text { peaks, rare (HI not } \\
\text { calculated for this } \\
\text { pattern) }\end{array}$ & $\begin{array}{l}\text { Scatter pattern, } \\
\text { indicates chaotic } \\
\text { behavior of turbidity } \\
\text { and discharge values, } \\
\text { not likely to encounter, } \\
\text { extremely rare (HI not } \\
\text { calculated for this } \\
\text { pattern) }\end{array}$ \\
\hline
\end{tabular}

Figure 1. Dominant hysteresis patterns explained

The unique aspect of this study is that we applied these techniques in three adjacent watersheds with different degrees of urban development where discharge and turbidity relationships may shift throughout the wet season. We hypothesize that turbidity values are likely to peak earlier than discharge in more urbanized watersheds and that frequent and intense precipitations can significantly elevate discharge and turbidity levels. Additionally, the relation between discharge and turbidity will be different between the early and later wet season as the source of sediment depleted, but the strength of the relation would vary by watershed land characteristics. We seek to investigate the following questions.

(1) How do the hysteresis index, loop direction, and type vary across early (i.e., October-November), mid (i.e., December - February), and late (i.e., March-May) wet seasons and a land cover gradient?

(2) How are turbidity, discharge, and precipitation related to each other at different times of the wet season and by watershed? 
(3) How are maximum turbidity values explained by precipitation and discharge variables and how sensitive are maximum turbidity to changes in discharge range by watershed, season, and flashiness? 


\section{Methods}

\subsection{Study Area}

The study areas are three urbanizing river basins in the Portland-Metro area of the Lower Willamette River Basin. The Lower Willamette River Basin contains the most densely developed area within the state of Oregon. We have selected two USGS stream gages from each watershed, one from a more upstream/rural area, and the other more urbanized station further downstream closer to the outlet of the watershed (Figure 2). Although close to each other, the studied watersheds are very different in size, land cover, soil type, and hydrology.

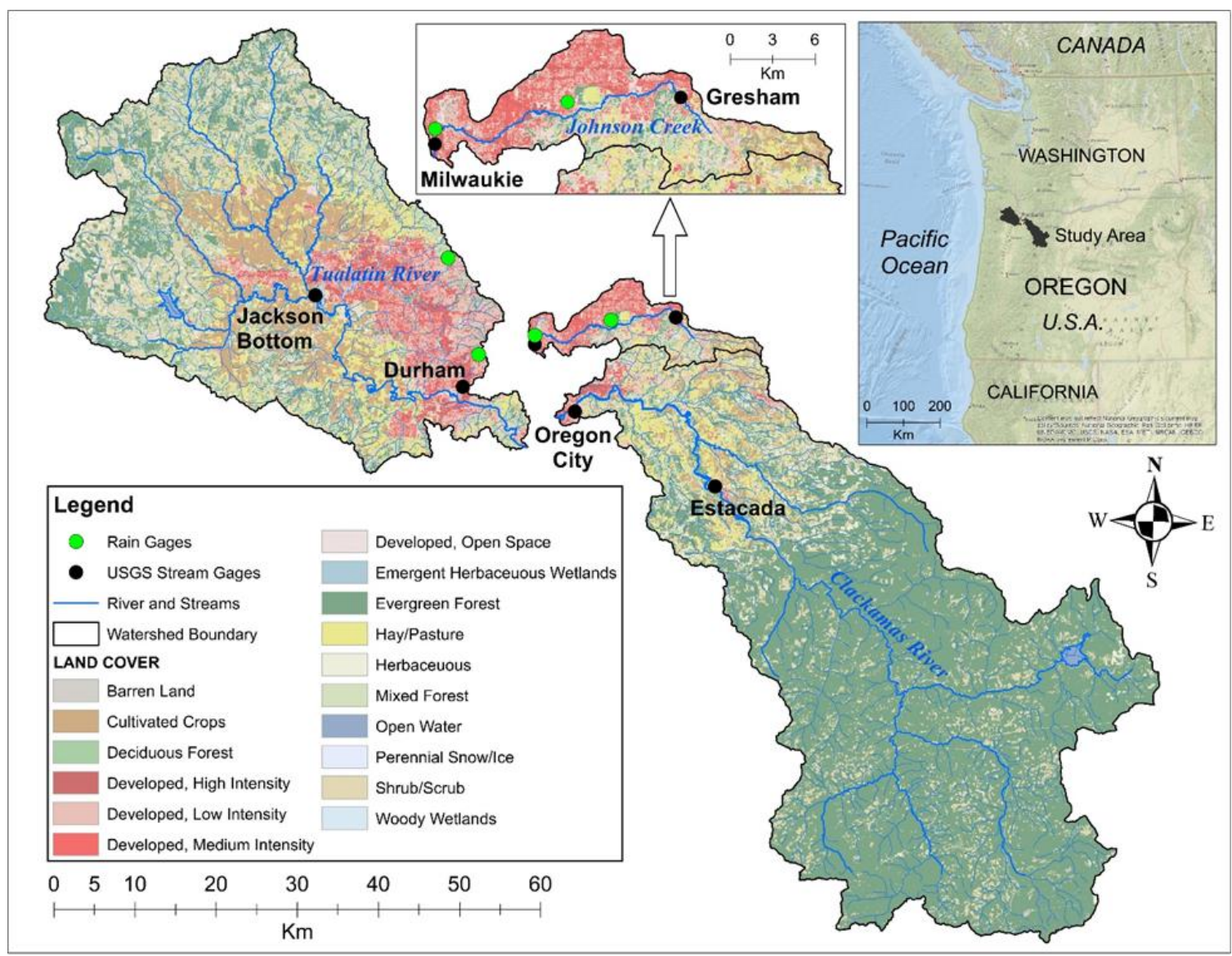

Figure 2. Map of study area land cover and monitoring sites 
The study area exhibits a Mediterranean climate with prolonged winter rainfall and summer drought. Precipitation in the basin mainly occurs as rainfall between September and May, except for the upper Clackamas watershed where winter snow becomes an essential component of runoff in subsequent summer. Land cover in the watersheds is dominated by forest in uplands and urban and agricultural area in low laying areas (Table 1).

Table 1. Land and hydrological characteristics of stations in the study area

\begin{tabular}{|c|c|c|c|c|c|c|}
\hline Watershed & \multicolumn{2}{|c|}{ Tualatin } & \multicolumn{2}{|c|}{ Johnson Creek } & \multicolumn{2}{|c|}{ Clackamas } \\
\hline Station Name & Jackson Bottom & Durham & Milwaukie & Gresham & Oregon City & Estacada \\
\hline USGS ID & 14206241 & 14206950 & 14211550 & 14211400 & 14211010 & 14210000 \\
\hline Area (sqkm) & 324.8 & 80.7 & 138 & 40 & 2435 & 1763 \\
\hline Station Elevation (m) & 40 & 39 & 9 & 98 & 9 & 93 \\
\hline Slope & 16.2 & 5.9 & 5.5 & 7.3 & 21.4 & 24.9 \\
\hline Mean Watershed Elevation (m) & 310.9 & 100.9 & 119.9 & 176.8 & 830.3 & 1012.5 \\
\hline $\begin{array}{l}\text { Mean Annual Precipitation } \\
\text { (cm) }\end{array}$ & 161.09 & 107.3 & 134 & 156 & 185 & 192 \\
\hline Mean Annual Runoff (cm) & 104.25 & 60.28 & 80.42 & 90.23 & 138.34 & 148.12 \\
\hline Rainfall-Runoff Ratio & 0.65 & 0.56 & 0.60 & 0.58 & 0.75 & 0.77 \\
\hline Baseflow Index & 49.4 & 45.5 & 46.7 & 48.7 & 65.9 & 70.8 \\
\hline$\%$ Impervious Surfaces & 0.82 & 39.52 & 30.31 & 9.41 & 0.87 & 0.09 \\
\hline$\%$ Land Cover (Urban) & 7 & 89 & 68 & 37 & 6 & 1 \\
\hline$\%$ Land Cover (Farm) & 24 & 3 & 17 & 40 & 8 & 1 \\
\hline \% Land Cover (Forest) & 69 & 8 & 15 & 23 & 86 & 98 \\
\hline \% Hydro Soil Group A & 0 & 0 & 0.06 & 0 & 2.26 & 2.98 \\
\hline \% Hydro Soil Group B & 66.04 & 3.95 & 28.37 & 7.81 & 54.84 & 60.71 \\
\hline \% Hydro Soil Group C & 23.21 & 76.18 & 50.99 & 85.19 & 37.88 & 31.08 \\
\hline \% Hydro Soil Group D & 10.75 & 19.87 & 20.58 & 7 & 5.02 & 5.23 \\
\hline Average Permeability $(\mathrm{cm} / \mathrm{hr})$ & 0.96 & 1.01 & 4.9 & 2.31 & 6.88 & 3.26 \\
\hline Dominant Geology Type & $\begin{array}{l}\text { Clayey \& loamy } \\
\text { colluvium; } \\
\text { poorly } \\
\text { consolidated } \\
\text { rocks }\end{array}$ & $\begin{array}{l}\text { Floodplain } \\
\text { and } \\
\text { alluvium } \\
\text { gravel } \\
\text { terraces }\end{array}$ & $\begin{array}{l}\text { Till, or } \\
\text { ground } \\
\text { moraine }\end{array}$ & $\begin{array}{l}\text { Colluvium } \\
\text { on } \\
\text { volcanic } \\
\text { rocks }\end{array}$ & $\begin{array}{l}\text { Floodplain } \\
\text { and alluvium } \\
\text { gravel } \\
\text { terraces }\end{array}$ & $\begin{array}{l}\text { Colluvium } \\
\text { on } \\
\text { volcanic } \\
\text { rocks }\end{array}$ \\
\hline
\end{tabular}

Majority of soil type in the Tualatin watersheds are group B (silt loam or loam, moderate infiltration rate) and $\mathrm{C}$ (sandy clay loam, low infiltration rate), and the watersheds sit on clay and loamy colluvium and poorly consolidated rocks (Table 1). In 
the Clackamas River, shallow soil with low runoff potential and steep topography in some parts of the basin, along with urbanization and logging are increasing the likelihood of moderate soil erosion during intense rainfall events. A few hydroelectric dams were constructed on the river to produce energy and water supply in Clackamas and Tualatin, respectively, and the dam reservoir operating regime can promote significant differences for river turbidity and sediment concentration below the dams (De Oliveira Naliato, Nogueira, \& Perbiche-Neves, 2009).

The Johnson Creek basin is the smallest of the three watersheds with mixed land use gradient from forested, rural-agriculture, to the urban-industrial area. The dominant soil group in this watershed is Group $\mathrm{C}$ with low infiltration rate, which has moderately high runoff potential when it is wet, along with high urban land cover and percentage of impervious surfaces which in turn can all contribute to greater erosion and sediment loss during storms. Johnson Creek's elongated shape and narrow channels cause storm hydrographs to be often flashier, which prompted us to investigate and compare the flashiness of each watershed. The Durham station represents the sub-basin of the most developed portion of the Tualatin Basin.

\subsection{Data}

Six USGS gaging stations were chosen to obtain discharge and turbidity data from the water year 2008 to 2017 (Table 1). Discharge and turbidity data were only analyzed for the wet season, defined as between October $1^{\text {st }}$ and May $29^{\text {th }}$. Summer months were neglected in this study because the chosen watersheds do not receive a significant amount of precipitation during the dry season. Hourly precipitation data were collected from the 
nearest Portland Hydra Rainfall Network stations during the study period. The closest rain gage for each stream gage was chosen and mapped in Figure 2. Because there were no nearby rain gages in Clackamas, we used hourly rainfall data from Johnson Creek.

\subsection{Methods}

\subsubsection{Storm Identification}

Identifying storms and heavy precipitations events were challenging because hydroclimate in the Pacific Northwest is highly influenced by seasonality, atmospheric circulation patterns, and the Cascade mountain range. All three watersheds are in the low-lying valleys west of the Cascades, which exhibit mild year-round temperatures, substantial rainfall during the winter, and higher accumulation of precipitation in upper

altitudes. Taking into account the regional climate and hydrology (Van Kirk \& Naman, 2008), we decided the most suitable approach for our watershed was to identify storm turbidity response events with elevated discharge levels from precipitation. Namely, we used a $20 \%$ threshold exceedance of the monthly average baseflow (Gonzales, Nonner, Heijkers, \& Uhlenbrook, 2009; Lloyd et al., 2016b). The duration of each major discharge event was limited to less than seven days to separate individual events. Discharge peaks were separated if the storms occurred more than 24 hours apart and grouped if the time between multiple peaks were no more than 8 hours apart. Half-hourly discharge data were collected at the beginning of the rising curve of the hydrograph until discharge values returned to the initial state before the storm. Corresponding turbidity values were also obtained for the same timeframe every 30 minutes. Storms were 
identified for all selected stations beginning in October 2008 and ending in May 2017 and categorized based on seasonality.

\subsubsection{Hysteresis Models}

Hysteresis models, which have been used to interpret the cyclic pattern between discharge and concentration, can quantify by indices to assess the difference in hysteresis loop shape and direction at multiple time and space scales. Usually, hysteresis loops exhibit either circular, eight-shaped, linear, or scatter behavior for discharge and turbidity (Asselman, 1999; Moog \& Whiting, 1998; Williams, 1989). Several dimensionless hysteresis indices (HI) have been developed to quantify the magnitude and direction of hysteresis loops. Langlois et al. (2005) developed a method to quantify the hysteresis index by splitting the hydrograph into raising and falling curve then calculate the ratio under the regression curve between them. Lawler et al. (2006) calculated hysteresis index based on interpolated turbidity values at the rising and falling limb at the mid-point of streamflow during each event between baseflow and peak discharge. Lloyd et al. (2016) further improved the Lawler method by normalizing both discharge and turbidity data at every measuring point. HI values were calculated at multiple intervals of the discharge curve and averaged to obtain an index between -1 and 1 . However, these methods do not accurately reflect figure-of-eight shape loops where hysteresis change direction in a single storm event. Zuecco et al. (2016) took into account the possibilities of increasing and decreasing independent variable (discharge) and dependent variable (turbidity) at any time of the storm by computing the definite integrals on the curves of discharge. This method yields eight new hysteresis class as shown in Table 2 and still undergoes 
normalization of the two variables before the computation of the definite integrals. If the integrals of the rising curve are larger than the falling curve, then the loop is clockwise $(\mathrm{HI}>0)$, and vice versa for anticlockwise $(\mathrm{HI}<0)$ loops. When $\mathrm{HI}$ values approach 0 , it indicates hysteresis pattern is either figure-of-eight or complex. The larger the absolute value of HI, the "fatter" the loop area, indicating the longer lag time between discharge and turbidity peaks. We examined the temporal variability of hysteresis index and loop patterns by season and looked for spatial variability across all six studied stations with an emphasis on precipitation, discharge, and turbidity parameters.

\subsubsection{Statistical Analysis}

Spearman's rank non-parametric correlation model was used to compare discharge, turbidity, and precipitation variables for each identified storm. Variables compared were discharge range; turbidity maximum, hysteresis index, and 3-day cumulative precipitation. Correlation coefficients for storms in each studied station were calculated on two different time scales (water year and season). For turbidity and discharge variables, a positive logarithmic relationship has been observed in previous studies (Pietroń et al., 2015; Williams, 1989) between sediment concentration and discharge. We used log-transformed turbidity values, due to the highly skewed distribution of the data to construct similar regression with log-transformed discharge. For other variables, the regular linear regression models were used to test the contribution of each independent variables (discharge and cumulative precipitation) and their ability to predict the dependent variable (turbidity). Linear regression line slope equations were calculated along with the coefficient of determination $\left(\mathrm{R}^{2}\right)$. To test the relation of flashy 
behaviors of urban streams and turbidity, we calculated a flashiness index using methods by (Baker et al., 2004) which has not been examined in previous studies. The RichardBaker Index (RBI) equation used in this study is as follows, where $q$ is mean daily flow.

$$
\text { R-B Index }=\frac{\sum_{i=1}^{n}\left|q_{i}-q_{i-1}\right|}{\sum_{i=1}^{n} q_{i}}
$$




\section{Results}

\subsection{Hysteresis Analysis}

Classification of hysteresis loops showed that class II clockwise figure-of-eight is the most dominant type across the stations (35\%), except Estacada and Jackson Bottom, which both exhibit a large percentage of agricultural and forest land cover (Table 2). Clackamas River watershed stations had the most storm events to exhibit anticlockwise loop direction $(62 \%)$ possibly associated with the largest forest land cover $(<86 \%)$. Tualatin watershed stations had the least number of anticlockwise loops (only $21 \%$ of all analyzed hysteresis loops). Johnson Creek watershed showed somewhat even split (62\% clockwise vs. $38 \%$ anticlockwise). Hysteresis class I through IV were the most common classes for storms identified across all stations. While most stations showed only a few class IV hysteresis (circular anticlockwise), the Estacada station showed 25, which matched our initial hypothesis that discharge peaks after turbidity in watersheds with the most forest land cover. No visible seasonal variability was observed across hysteresis class, and loop direction for all the study sites, the mid wet season had the most identified loops because the majority of storms occurred between December and February in the Pacific Northwest. The calculated hysteresis index derived from Zuecco et al., (2016) showed that Estacada and Jackson Bottom had a larger average absolute value of the hysteresis index compared to the other four stations (Figure 3), suggesting a greater lag time between discharge and turbidity.

Table 2. Hysteresis loop classifications of identified storms from WY 2009-2017, hysteresis class loops are drawn according to Zuecco et al. (2016), where C stands for clockwise, and AC stands for anticlockwise 


\begin{tabular}{|c|c|c|c|c|c|c|c|c|c|c|}
\hline \multirow{2}{*}{ Station } & \multicolumn{8}{|c|}{ Hysteresis Class } & \multicolumn{2}{|c|}{$\begin{array}{c}\text { Loop } \\
\text { Direction }\end{array}$} \\
\hline & $\mathrm{I}$ & II & III & IV & $\mathrm{V}$ & VI & VII & VIII & & \\
\hline $\begin{array}{l}\text { Tualatin } \\
\text { Jackson } \\
\text { Bottom }\end{array}$ & $\mathrm{C}$ & $\mathrm{C}$ & $\mathrm{AC}$ & $\mathrm{AC}$ & $\mathrm{C}$ & $\mathrm{C}$ & $\mathrm{AC}$ & $\mathrm{AC}$ & & \\
\hline Oct - Nov & 8 & 2 & 2 & 1 & - & - & - & - & 10 & 3 \\
\hline Dec - Feb & 6 & 3 & 1 & - & - & 1 & - & - & 10 & 1 \\
\hline $\begin{array}{l}\text { Mar - } \\
\text { May }\end{array}$ & 7 & 1 & 3 & - & - & - & - & - & 8 & 3 \\
\hline Durham & 21 & 6 & 6 & 1 & - & 1 & - & - & 28 & 7 \\
\hline Oct - Nov & 8 & 21 & 2 & - & - & - & - & - & 29 & 2 \\
\hline Dec - Feb & 8 & 16 & 9 & - & 1 & - & - & - & 25 & 9 \\
\hline $\begin{array}{l}\text { Mar - } \\
\text { May }\end{array}$ & 2 & 12 & 6 & 2 & - & - & - & - & 14 & 8 \\
\hline $\begin{array}{l}\frac{\text { Johnson }}{\text { Creek }} \\
\text { Milwauki } \\
\text { e }\end{array}$ & 18 & 49 & 17 & 2 & 1 & - & - & - & 68 & 19 \\
\hline Oct - Nov & 2 & 7 & 5 & - & - & - & 1 & - & 9 & 6 \\
\hline Dec - Feb & 10 & 10 & 8 & 3 & - & - & 1 & - & 21 & 11 \\
\hline $\begin{array}{l}\text { Mar - } \\
\text { May }\end{array}$ & 1 & 7 & 4 & 2 & - & - & 1 & - & 8 & 7 \\
\hline Gresham & 13 & 24 & 17 & 5 & - & - & 3 & - & 38 & 24 \\
\hline $\begin{array}{l}\text { Oct - Nov } \\
\text { Dec - Feb }\end{array}$ & $\begin{array}{c}5 \\
15\end{array}$ & $\begin{array}{c}4 \\
14\end{array}$ & $\begin{array}{l}2 \\
9\end{array}$ & 2 & - & - & - & - & $\begin{array}{c}9 \\
30\end{array}$ & $\begin{array}{l}4 \\
9\end{array}$ \\
\hline $\begin{array}{l}\text { Mar - } \\
\text { May }\end{array}$ & 4 & 5 & 13 & - & - & - & 1 & - & 9 & 14 \\
\hline $\begin{array}{l}\text { Clackama } \\
\underline{\mathrm{s}} \\
\text { Oregon } \\
\text { City }\end{array}$ & 23 & 24 & 24 & 2 & - & 1 & 1 & - & 48 & 27 \\
\hline Oct - Nov & 3 & 5 & 2 & 1 & 1 & - & - & - & 9 & 3 \\
\hline Dec - Feb & 9 & 9 & 7 & 4 & 1 & 2 & - & - & 21 & 11 \\
\hline $\begin{array}{l}\text { Mar - } \\
\text { May }\end{array}$ & - & 10 & 5 & - & - & - & - & - & 10 & 5 \\
\hline Estacada & 12 & 24 & 14 & 5 & 2 & 2 & - & - & 40 & 19 \\
\hline Oct - Nov & - & 1 & 8 & 4 & - & - & - & - & 1 & 12 \\
\hline Dec - Feb & - & 4 & 11 & 15 & - & - & - & - & 4 & 26 \\
\hline $\begin{array}{l}\text { Mar - } \\
\text { May }\end{array}$ & - & - & 10 & 6 & - & - & - & - & 0 & 16 \\
\hline & - & 5 & 29 & 25 & - & - & - & - & 5 & 54 \\
\hline Total & 87 & 132 & 107 & 40 & 3 & 4 & 4 & - & 227 & 150 \\
\hline (\% total) & 23 & 35 & 28.3 & 10.6 & 0.7 & 1 & 1 & - & 60 & 40 \\
\hline
\end{tabular}


Although both Jackson Bottom and Estacada are both dominated by forest land cover,

Jackson Bottom showed more clockwise loops, suggesting that there may be other

sources of sediment (e.g., from agricultural lands) that can quickly enter streams

following a storm. Other more urbanized stations with smaller absolute HI values

indicated a shorter lag time and possible quicker flushing of sediment into streams, which is expected compared to previous studies.

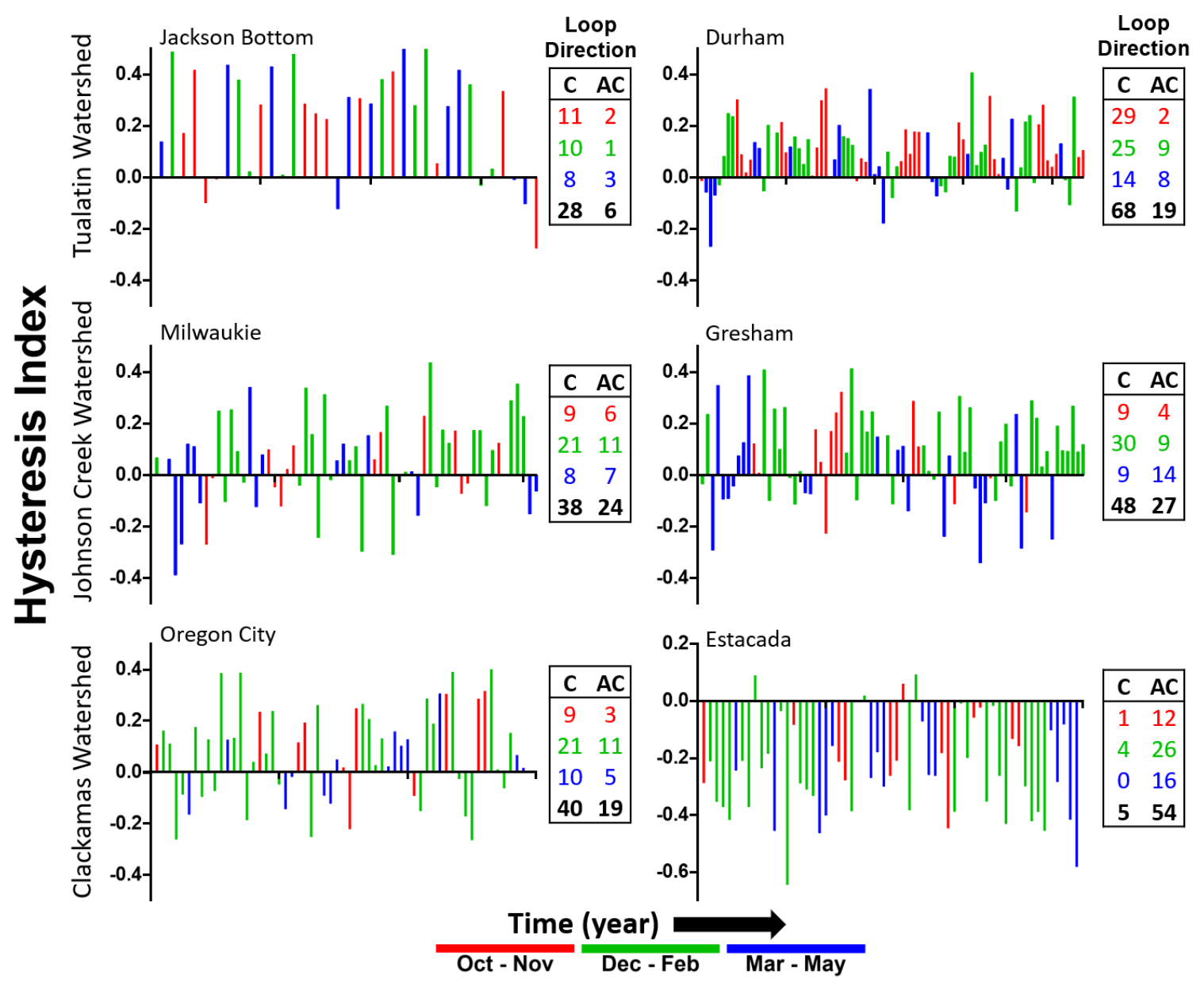

Figure 3. Hysteresis index by study site and season for all analyzed storms 


\subsection{Correlation Analysis}

Table 3 displays two positive correlation (Discharge \& Turbidity; Turbidity and Precipitation) that exhibited the highest performance $(0.22<\rho<0.91)$ at the 0.01 significant level. Discharge is moderately and strongly related to turbidity either in the beginning (Oct - Nov) or middle (Dec - Feb) of the wet seasons, except the Durham station. Johnson Creek stations showed consistent correlation coefficients across all seasons, while Tualatin and Clackamas watershed stations showed a higher variation of correlation across seasons. For discharge and turbidity relationship in the Johnson and Clackamas, mid wet season (Dec $-\mathrm{Feb}$ ) showed the most statistically significant $\rho$ values for the more urbanized downstream stations (Milwaukie and Oregon City), while early wet season (Oct - Nov) exhibited the highest correlation coefficient for upstream stations (Gresham and Estacada).

Table 3. Spearman's rank correlation coefficients values by study sites and season (*significant at the 0.1 level; ** significant at the 0.05 level; $\mathrm{n}=$ sample size). Highest correlation coefficient values are shaded for each location.

\begin{tabular}{llllllll}
\hline \multirow{1}{*}{ Station } & \multicolumn{3}{c}{ Discharge \& Turbidity } & \multicolumn{3}{c}{ Turbidity \& Precipitation } \\
& Oct - Nov & Dec - Feb & Mar - May & Oct - Nov & Dec - Feb & Mar - May \\
\hline Jackson & $0.70^{* *}$ & $0.88^{* *}$ & 0.46 & 0.50 & 0.31 & 0.07 \\
Bottom & $(\mathrm{n}=13)$ & $(\mathrm{n}=11)$ & $(\mathrm{n}=11)$ & $(\mathrm{n}=13)$ & $(\mathrm{n}=11)$ & $(\mathrm{n}=11)$ \\
& 0.10 & 0.14 & $0.51^{*}$ & 0.15 & 0.22 & $0.54 *$ \\
Durham & $(\mathrm{n}=31)$ & $(\mathrm{n}=34)$ & $(\mathrm{n}=22)$ & $(\mathrm{n}=31)$ & $(\mathrm{n}=34)$ & $(\mathrm{n}=22)$ \\
& $0.78^{* *}$ & $0.79 * *$ & $0.79 * *$ & $0.81^{* *}$ & $0.66^{* *}$ & $0.66^{* *}$ \\
Milwaukie & $(\mathrm{n}=15)$ & $(\mathrm{n}=32)$ & $(\mathrm{n}=15)$ & $(\mathrm{n}=15)$ & $(\mathrm{n}=32)$ & $(\mathrm{n}=15)$ \\
& $0.56^{*}$ & $0.42^{* *}$ & $0.52^{*}$ & 0.32 & $0.42^{* *}$ & 0.41 \\
Gresham & $(\mathrm{n}=13)$ & $(\mathrm{n}=39)$ & $(\mathrm{n}=23)$ & $(\mathrm{n}=13)$ & $(\mathrm{n}=39)$ & $(\mathrm{n}=23)$ \\
\multirow{5}{*}{ Oregon City } & $0.73^{*}$ & $0.89 * *$ & $0.68^{* *}$ & $0.65^{*}$ & $0.56^{* *}$ & $0.72 * *$ \\
& $(\mathrm{n}=11)$ & $(\mathrm{n}=33)$ & $(\mathrm{n}=15)$ & $(\mathrm{n}=11)$ & $(\mathrm{n}=33)$ & $(\mathrm{n}=15)$ \\
\multirow{3}{*}{ Estacada } & $0.91^{* *}$ & $0.71 * *$ & $0.84 * *$ & 0.22 & $0.63 * *$ & $0.67 * *$ \\
& $(\mathrm{n}=13)$ & $(\mathrm{n}=30)$ & $(\mathrm{n}=16)$ & $(\mathrm{n}=13)$ & $(\mathrm{n}=30)$ & $(\mathrm{n}=16)$ \\
\hline
\end{tabular}


Of all the stations compared, Gresham and Durham had the lowest overall average $\rho$ values while Milwaukie and Oregon City has the highest overall average $\rho$ values. For turbidity and precipitation, correlation coefficients were highest at the end of the wet season, except for Johnson at Milwaukie.

\subsection{Regression Analysis}

For the $\log \mathrm{Q}$ range and $\log$ maximum turbidity model, two larger downstream stations - Oregon City and Milwaukie - demonstrated the highest $\mathrm{R}^{2}$ values. The other upstream stations show lower $\mathrm{R}^{2}$ values (Figure 4). Turbidity values increase faster with discharge at Oregon City and Estacada stations, both showed a slope greater than 1 (1.4 in Oregon City and 1.2 in Estacada) and are located in the Clackamas River watershed. According to the relationship between suspended sediment concentration and discharge levels illustrated in Eder et al. (2010), developed or disturbed watersheds had steeper slopes in the relation between SSC and discharge than rural watersheds. This fits our expectations because Johnson Creek watershed is more heavily developed than Clackamas River watershed. However, the slope of the Durham station, the most developed and smallest watershed was smallest among the stations examined.

Linear regression models showed weak to moderate association between turbidity maximum and cumulative precipitation. Although all stations showed positive slopes between the tested variables, the Milwaukie station exhibited the highest $\mathrm{R}^{2}$ values ranging from 0.53 to 0.79 (Figure 5). In contrast, the Durham station showed the lowest $\mathrm{R}^{2}$ values. Given that both watersheds are the most urbanized among the six stations, these contrasting results are interesting. Overall, both average event turbidity values and 
cumulative precipitation are the highest at Milwaukie.
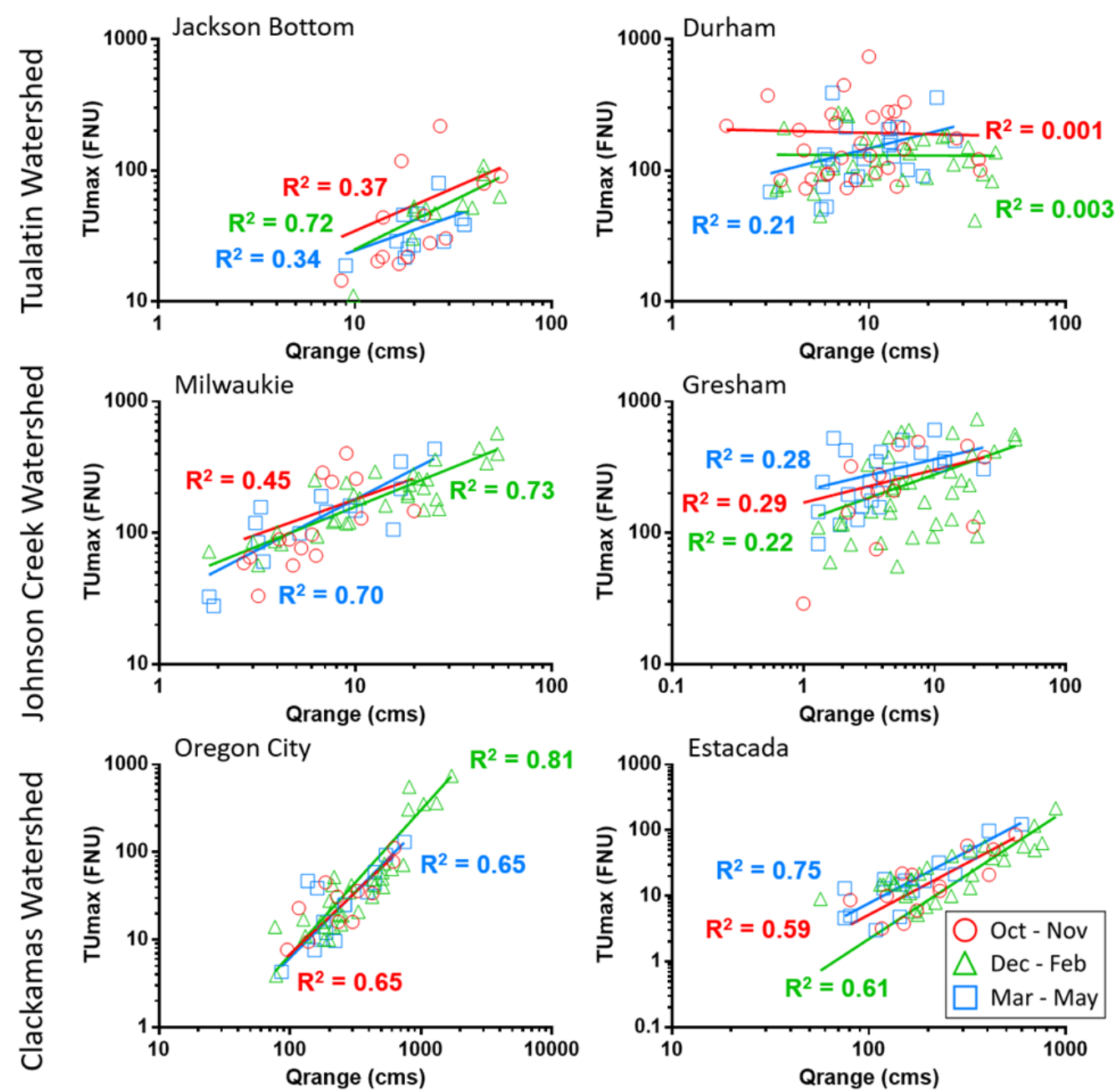

Figure 4. Discharge range and turbidity maximum rating curves by nonlinear regression model at studied sites; $n=35$ (Jackson Bottom), n=87 (Durham); n=62 (Milwaukie), n=75 (Gresham), n=59 (Oregon City \& Estacada)

While both watersheds have high impervious covers (over 30\%), other landscape factors such as size, slope, and near stream land conditions could explain such differences in the relationship between precipitation and turbidity. Lastly, the R-B flashiness index was found to be negatively correlated $\left(r=0.70, R^{2}=0.49\right)$ with the slope of trend lines between turbidity and discharge, indicating that the flashier the stream, the smaller the predictability of turbidity based on discharge (Figure 6). 

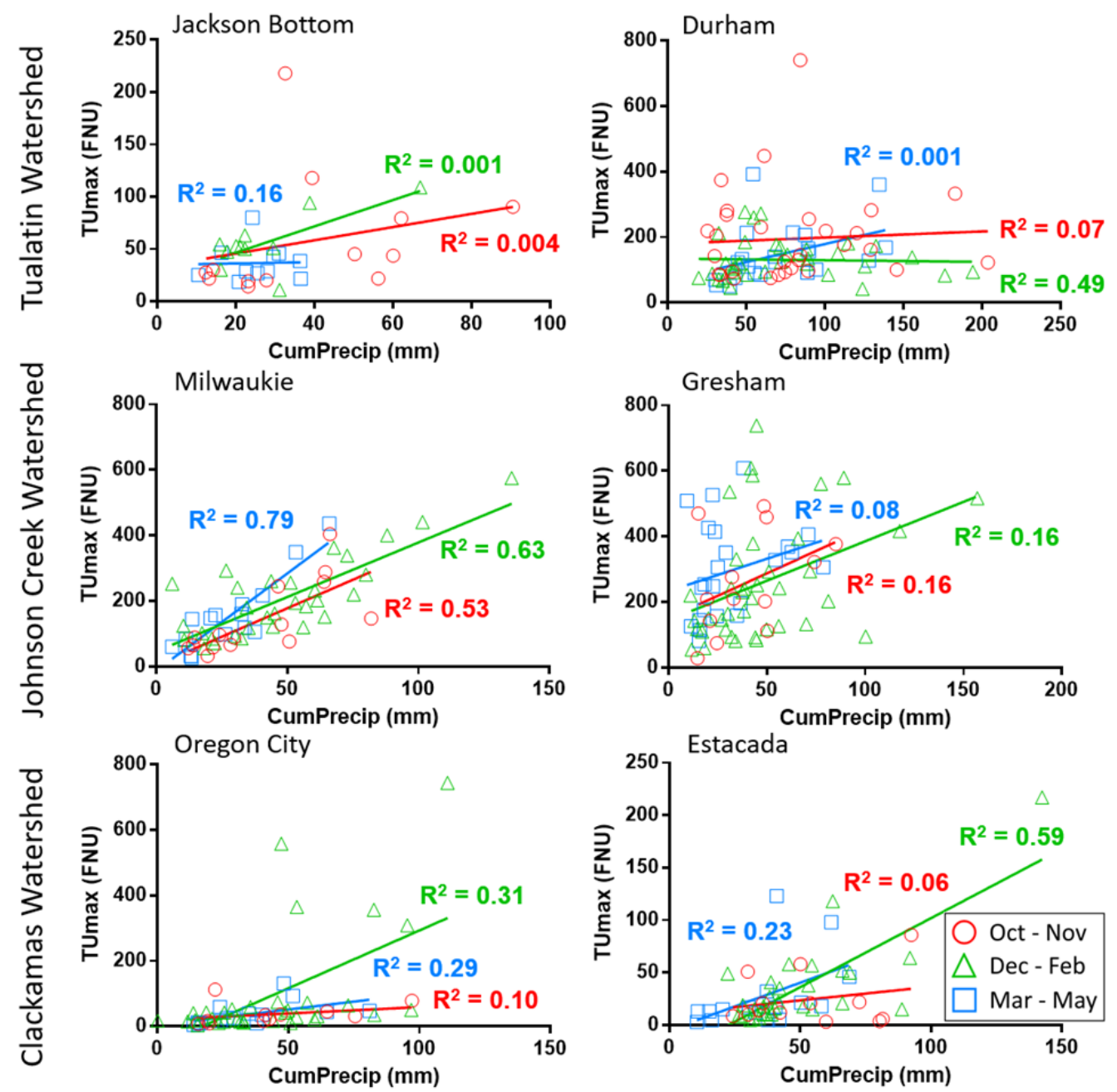

Figure 5. Linear regression models of turbidity maximum and cumulative precipitation for study sites; $\mathrm{n}=35$ (Jackson Bottom), $\mathrm{n}=87$ (Durham), $\mathrm{n}=62$ (Milwaukie), $\mathrm{n}=75$ (Gresham), n=59 (Oregon City \& Estacada)

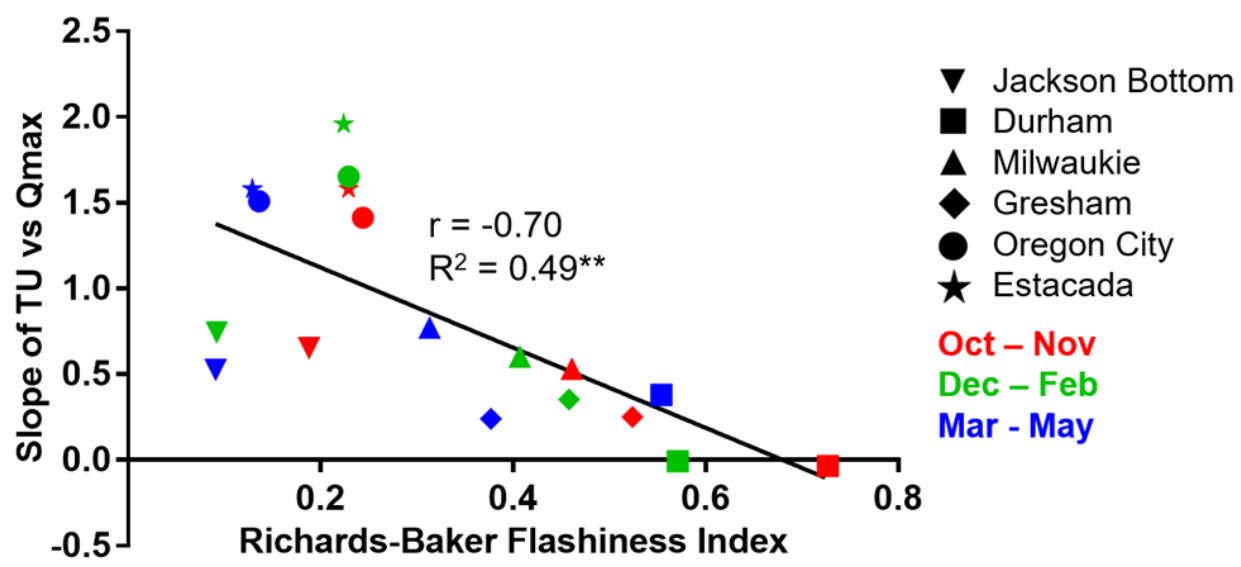

Figure 6. Relation between flashiness index and slope of turbidity vs discharge 


\section{Discussion}

\subsection{Hysteresis loop classification and patterns}

Storm hysteresis patterns vary in space and time due to the nature of individual storm events , basin morphology, and antecedent soil conditions (Lawler et al., 2006). Sherriff et al. (2016) highlighted that hydrological connectivity and source availability of watersheds can alter hysteresis responses significantly. Our classification of hysteresis loops showed that loop patterns matched with previous studies (Pietron et al., 2015) where clockwise loops are more dominant than anticlockwise. Observations of clockwise loops can be explained by the nature of quick sediment flushing and a nearby readily available sediment source. Clockwise loops are dominantly occurring in shallow urban streams where in-channel deposits, which had been accumulated from previous events, can be resuspended during high flow events. As a result, we observed that mid wet season between December and February when storm occurrence frequency is high, the number of figure-of-eight clockwise loops were also high. Extensive near-channel erosion and resuspension of sediment are likely the cause of earlier peaking turbidity values in our studied urban watersheds. However, the loop direction may switch halfway during a storm event if the limited sediment source is exhausted. On the other hand, we expected the most forested watershed to have the most anticlockwise loop direction, and our hypothesis was confirmed since Estacada loops were dominantly anticlockwise. This anticlockwise behavior occurred in more rural watershed, confirming a previous study's conclusion that turbidity peaks lag behind discharge peaks in agricultural watersheds (Eder et al., 2010). 
Furthermore, the majority of our urbanized sites exhibited more clockwise behavior, confirmed our hypothesis that urban stream's high flow velocity could generate more suspended sediment at a short period of time following a storm (Salvadore et al., 2015). The proximity of hillslope erosion may be farther away in well- preserved watersheds, because most soil is well-drained, and complex vegetation cover and stream channel may have slowed down the transport and delivery of eroded sediments. Depletion of available turbidity causing sediment can be observed through hysteresis loop in individual events or over the seasons. We observed that within one watershed, a dominant hysteresis loop changed from clockwise to anticlockwise over time. This pattern can also be seen in Figure 3 that in clockwise hysteresis dominated sites, the anticlockwise loops typically occurred in middle and wet seasons when suspended solids may be exhausted after a sequence of storms. This shift in multi-event scale loop direction indicates that upstream sediment source may also be depleted over the wet season.

\subsection{Climate and seasonality on turbidity behaviors}

Precipitation amount and seasonal patterns can also account for variations in turbidity peak timing. The highest correlation between precipitation and turbidity in both Clackamas watershed stations in the late wet season may be explained by the characteristics of precipitation in the watershed. Snow is an important source of flow in late season flow for the upper part of the watershed that are located in higher elevation. Larger watersheds accumulate more precipitation that falls as snow and rain, which also allows for higher infiltration from forests (Botter et al., 2007). 
Additionally, rain-on-snow events could trigger a flashy spike in discharge levels during storms (Merz \& Blöschl, 2003). During early and mid-wet seasons, snow falls in the upper basin may not generate immediate flow (Graves \& Chang, 2007). Therefore, precipitation by rain is likely contributing partially to elevated discharge and turbidity levels at the beginning of the wet season.

Additionally, several dams on the Clackamas River regulate flow during early and mid-wet seasons, influencing streamflow volume and timing and sediment dynamics during storms by releasing water periodically. In contrast, Johnson Creek's lower elevation (rain dominant), narrow channel, and higher impervious surface areas result in flashier hydrographs during storms throughout the year, which may have contributed to a higher correlation between precipitation and turbidity. The Tualatin watershed receives less snow precipitation than the Clackamas watershed and lower average soil permeability from decades of farming practices. However, the rainfall-runoff ratio remains identical to the other two watersheds, suggesting low infiltration rates. We anticipated high turbidity and precipitation correlation during colder seasons when soil permeability is low, but our results indicated otherwise. The combination of these factors caused the Tualatin river turbidity levels to be less sensitive to change in precipitation intensity and therefore had lower variation between seasons compared to the other two watersheds. Our observation showed high correlation during late wet seasons for the two most rural watersheds, suggesting antecedent conditions like soil moisture levels (Penna, Tromp-Van Meerveld, Gobbi, Borga, \& Dalla Fontana, 2011) could be affecting infiltration and runoff rates, therefore affecting sediment erosions at early and mid-wet seasons (Baker \& Showers, 2019; Gray et al., 2015). 


\subsection{Landscape variations and urbanization on turbidity}

Seasonal variation of turbidity behaviors in this study is primarily driven by climate, while the spatial variations of elevated turbidity timing and magnitude are more influenced by many landscape factors (S. C. Sherriff et al., 2015; Vaughan, Belmont, Hawkins, \& Wilcock, 2017). In general, the stronger relations between turbidity maximum and discharge were found in watersheds that have a higher proportion of forest land cover (e.g., Estacada, Oregon City and Jackson Bottom). Small urban watersheds such as Durham and Gresham had weak relationships between turbidity and discharge. The only exception is Milwaukie that only had approximately $15 \%$ of forest land cover. From this observation, we can only conclude that more rural watersheds may be part of the reason turbidity levels are more sensitive to change in discharge during storms. The low slope of turbidity and discharge regression in Durham $\left(\mathrm{R}^{2}=0.001\right)$ and Gresham $\left(\mathrm{R}^{2}=0.18\right)$ is likely attributed to a high percentage of impervious urban surfaces, and runoff from paved roads (McGrane, 2016).

Additionally, the heterogeneity of urban landscape could play a role in affecting the discharge and turbidity relationship. Alteration to streambanks in these two subwatersheds may include green infrastructures that can cause sediment erosions to be reduced while flow over impervious surfaces picks up pollutants such as oil, gasoline, and trash. These substances are carried directly into storm drains and into streams without filtration, although they cause serious pollution, they are not likely contributing to the increase of turbidity values directly. With relatively steeper slope and a mosaic of patchy development, storm drains carry storm runoff directly to streams without contacting land 
surface areas, which could have contributed to the weak relation between discharge and turbidity. Another trend that emerged through the linear regression model was that downstream stations showed higher $\mathrm{R}^{2}$ values, suggesting that small scale variations that drive differences are likely to get dampened in larger watersheds by the laws of averaging (Pilgrim, Cordery, \& Baron, 1982). This pattern was explained by the difference in drainage area and degrees of development, which can impact rates of infiltration (Redfern et al., 2016).

One major difference between urban streams and rural streams is the flashiness of streams. Although our flashiness index showed that stations in urban areas do exhibit flashier behavior, to our surprise, higher flashiness in urban watersheds resulted in a strong negative correlation with the turbidity vs. discharge relationship. This result is unexpected and contradicts our hypothesis because our result indicated that as the hydrograph got flashier in smaller and narrower streams, the discharge becomes a weaker predictor for turbidity values. Urban stream flashiness or the urban stream syndrome usually results in rapid flooding, from the anthropogenic alteration of stream banks, narrowing channel with near stream impervious surfaces, as well as lack of proper drainage (McGrane, 2016). Although urban streams are flashy and allow stormwater to enter streams rapidly and increase streamflow velocity, it does not necessarily mean that these storm runoffs carry large loads of sediments. In urban settings where land cover type is mostly dense development, roads, and paved sidewalks, rainwater entering streams may carry pollutants and nutrients is. Source and location of sediment erosion depended largely on the near-channel condition, as well as the spatial distribution of impervious and pervious spaces in the urban watershed and their proximity to streams 
and the density of stormwater pipes that bypass rainwater to streams quickly (Russell, Vietz, \& Fletcher 2019). Since our urban monitoring stations are all located in highly developed areas, elevated turbidity levels are most likely results of high flow velocity resuspending river bed sediments (Chang, Allen, Morse, \& Mainali, 2018). The source of resuspended sediment is usually nearby. Therefore, the reduced delivery time of these sediments may be one of many factors in driving turbidity peaks earlier than discharge peaks. 


\section{Conclusion}

This study showed that both climate and landscape variables are possible drivers of the hysteretic behaviors of the discharge-turbidity relationship in our study area. Our results demonstrated that clockwise hysteresis loops are more dominant in urban watersheds while anticlockwise loops are more frequently seen in well-preserved, forested watersheds. Sediment availability at the event scale or season scale is still driving the temporal differences in hysteresis loop direction and classification. While climate and seasonality are primary drivers of predictability between precipitation and turbidity, landscape factors were found to be more responsible for governing the relationship between discharge and turbidity. Spatial differences including land cover, drainage area, elevation, soil type, and impervious surfaces are likely the influencing turbidity dynamics by affecting the sediment source, transport, and delivery. Our results suggest that both precipitation and discharge are good predictors of turbidity levels in rural watersheds. This study showed the complexity in understanding the turbidity behavior in urban watersheds, given many variables that exist in urban settings were not measured, such as riparian conditions, connectivity of stormwater drains, urban infiltration rate, and high-resolution impervious surface data. Additionally, flashiness index analysis showed that discharge is not a good predictor for turbidity levels during storms in flashy streams. Findings from this paper can open doors for other researchers to explore turbidity behaviors in urban settings at a finer spatial and temporal scale if sufficient advance monitoring equipment is available. 


\section{References}

Asselman, N. E. M. 1999. Suspended sediment dynamics in a large drainage basin: The River Rhine. Hydrological Processes 13 (10):1437-1450.

Baker, D. B., R. P. Richards, T. T. Loftus, and J. W. Kramer. 2004. A new flashiness index: Characteristics and applications to Midwestern rivers and streams. Journal of the American Water Resources Association 40 (2):503-522.

Baker, E. B., and W. J. Showers. 2019. Hysteresis analysis of nitrate dynamics in the Neuse River, NC. Science of the Total Environment 652:889-899. https://doi.org/10.1016/j.scitotenv.2018.10.254.

Bhurtun, P., L. Lesven, C. Ruckebusch, C. Halkett, J. P. Cornard, and G. Billon. 2019. Understanding the impact of the changes in weather conditions on surface water quality. Science of the Total Environment 652:289-299. https://doi.org/10.1016/j.scitotenv.2018.10.246.

Botter, G., F. Peratoner, A. Porporato, I. Rodriguez-Iturbe, and A. Rinaldo. 2007. Signatures of large-scale soil moisture dynamics on streamflow statistics across U.S. climate regimes. Water Resources Research 43 (11):1-10.

Brasington, J., and K. Richards. 2000. Turbidity and suspended sediment dynamics in small catchments in the Nepal Middle Hills. Hydrological Processes 14 (14):2559-2574.

Chang, H., D. Allen, J. Morse, and J. Mainali. 2018. Sources of contaminated flood sediments in a rural-urban catchment: Johnson Creek, Oregon. Journal of Flood Risk Management :e12496. http://doi.wiley.com/10.1111/jfr3.12496 (last accessed 1 November 2018).

Chang, H., and T. N. Carlson. 2005. Water quality during winter storm events in Spring Creek, Pennsylvania USA. Hydrobiologia 544 (1):321-332.

Chang, H., and J. Jones. 2010. Climate change and freshwater resources in Oregon. http://works.bepress.com/heejun_chang/13/. 
Chen, H. J., and H. Chang. 2014. Response of discharge, TSS, and E. coli to rainfall events in urban, suburban, and rural watersheds. Environtal Science: Processes Impacts 16 (10):2313-2324. http://xlink.rsc.org/?DOI=C4EM00327F.

Cooley, A., and H. Chang. 2017. Precipitation Intensity Trend Detection using Hourly and Daily Observations in Portland, Oregon. Climate 5 (1):10. http://www.mdpi.com/2225-1154/5/1/10.

Dearmont, D., D. McCarl, and A. Tolman. 1998. water quality : A case study in Texas water treatment is increased by $\$ 95$ per million gallons. Water Resources Research 34 (4):849-853.

Eder, A., P. Strauss, T. Krueger, and J. N. Quinton. 2010. Comparative calculation of suspended sediment loads with respect to hysteresis effects (in the Petzenkirchen catchment, Austria). Journal of Hydrology 389 (1-2):168-176. http://dx.doi.org/10.1016/j.jhydrol.2010.05.043.

Foster, I. D. L. 1978. SEASONAL SOLUTE BEHAVIOUR OF STORMFLOW IN A SMALL AGRICULTURAL CATCHMENT. Catena 5:151-163.

Graves, David; Chang, H. 2007. Hydrologic Impacts of Climate Change in the Upper Clackamas River Basin, Oregon USA. Climate Research 33:143-157. http://www.int-res.com/articles/cr2007/33/c033p143.pdf (last accessed 6 December 2017).

Gray, A. B., G. B. Pasternack, E. B. Watson, J. A. Warrick, and M. A. Goñi. 2015. Effects of antecedent hydrologic conditions, time dependence, and climate cycles on the suspended sediment load of the Salinas River, California. Journal of Hydrology 525:632-649. http://dx.doi.org/10.1016/j.jhydrol.2015.04.025.

Jaeger, W. K., A. Amos, D. P. Bigelow, H. Chang, D. R. Conklin, R. Haggerty, C. Langpap, K. Moore, P. W. Mote, A. W. Nolin, A. J. Plantinga, C. L. Schwartz, D. Tullos, and D. P. Turner. 2017. Finding water scarcity amid abundance using human-natural system models. 114 (45). http://www.pnas.org.proxy.lib.pdx.edu/content/pnas/114/45/11884.full.pdf (last 
accessed 26 November 2018).

Jiufa, L., and Z. Chen. 1998. Sediment resuspension and implications for turbidity maximum in the Changjiang Estuary. Marine Geology 148 (3-4):117-124.

Jung, I.-W., H. Moradkhani, and H. Chang. 2012. Uncertainty assessment of climate change impacts for hydrologically distinct river basins. Journal of Hydrology 466-467:73-87. http://dx.doi.org/10.1016/j.jhydrol.2012.08.002 (last accessed 1 November 2018).

Lawler, D. M., G. E. Petts, I. D. L. Foster, and S. Harper. 2006. Turbidity dynamics during spring storm events in an urban headwater river system: The Upper Tame, West Midlands, UK. Science of the Total Environment 360 (1-3):109-126.

Lloyd, C. E. M., J. E. Freer, P. J. Johnes, and A. L. Collins. 2016a. Technical Note: Testing an improved index for analysing storm discharge-concentration hysteresis. Hydrology and Earth System Sciences 20 (2):625-632. .2016b. Using hysteresis analysis of high-resolution water quality monitoring data, including uncertainty, to infer controls on nutrient and sediment transfer in catchments. Science of the Total Environment 543:388-404. http://dx.doi.org/10.1016/j.scitotenv.2015.11.028.

Mather, A. L., and R. L. Johnson. 2014. Quantitative characterization of stream turbiditydischarge behavior using event loop shape modeling and power law parameter decorrelation. Water Resources Research 50 (10):7766-7779.

McGrane, S. J. 2016. Impacts of urbanisation on hydrological and water quality dynamics, and urban water management: a review. Hydrological Sciences Journal 61 (13):2295-2311. https://doi.org/10.1080/02626667.2015.1128084.

Merz, R., and G. Blöschl. 2003. A process typology of regional floods. Water Resources Research 39 (12):1-20. http://doi.wiley.com/10.1029/2002WR001952.

Moog, D. B., and P. J. Whiting. 1998. Annual hysteresis in bed load rating curves. Water Resources Research 34 (9):2393-2399. 
Oliveira, K. S. S., and V. da S. Quaresma. 2017. Temporal variability in the suspended sediment load and streamflow of the Doce River. Journal of South American Earth Sciences 78:101-115.

De Oliveira Naliato, D. A., M. G. Nogueira, and G. Perbiche-Neves. 2009. Discharge pulses of hydroelectric dams and their effects in the downstream limnological conditions: A case study in a large tropical river (SE Brazil). Lakes and Reservoirs: Research and Management 14 (4):301-314.

Penna, D., H. J. Tromp-Van Meerveld, A. Gobbi, M. Borga, and G. Dalla Fontana. 2011. The influence of soil moisture on threshold runoff generation processes in an alpine headwater catchment. Hydrology and Earth System Sciences 15 (3):689702.

Pietroń, J., J. Jarsjö, A. O. Romanchenko, and S. R. Chalov. 2015. Model analyses of the contribution of in-channel processes to sediment concentration hysteresis loops. Journal of Hydrology 527:576-589.

Ram, A. R., and J. P. Terry. 2016. Stream turbidity responses to storm events in a pristine rainforest watershed on the Coral Coast of southern Fiji. International Journal of Sediment Research 31 (4):279-290. http://dx.doi.org/10.1016/j.ijsrc.2016.07.002.

Redfern, T. W., N. Macdonald, T. R. Kjeldsen, J. D. Miller, and N. Reynard. 2016. Current understanding of hydrological processes on common urban surfaces. Progress in Physical Geography 40 (5):699-713.

Resler, K. E. 2011. Sediment based turbidity analysis for representative South Corolina soils.

Salvadore, E., J. Bronders, and O. Batelaan. 2015. Hydrological modelling of urbanized catchments: A review and future directions. Journal of Hydrology 529 (P1):6281. http://dx.doi.org/10.1016/j.jhydrol.2015.06.028.

Sherriff, S. C., J. S. Rowan, A. R. Melland, P. Jordan, O. Fenton, and D. O. Huallacháin. 2015. Investigating suspended sediment dynamics in contrasting agricultural 
catchments using ex situ turbidity-based suspended sediment monitoring. Hydrology and Earth System Sciences 19 (8):3349-3363.

Tuset, J., D. Vericat, and R. J. Batalla. 2016. Rainfall, runoff and sediment transport in a Mediterranean mountainous catchment. Science of the Total Environment 540:114-132. http://dx.doi.org/10.1016/j.scitotenv.2015.07.075.

Vaughan, A. A., P. Belmont, C. P. Hawkins, and P. Wilcock. 2017. Near-Channel Versus Watershed Controls on Sediment Rating Curves. Journal of Geophysical Research: Earth Surface 122 (10):1901-1923.

Walling, D. E., and B. W. Webb. 1980. r u n of f processes operating in a drainage basin ( e. g ., Steele , 1968a ; Nakamura , 1971 ; Walling and Foster , 1975 ; Kennedy and Malcolm , 1977 ). Similarly, information on temporal variations in ion concentrations during individual storm events. 47:129-149.

Williams, G. P. 1989. Sediment concentration versus water discharge during single hydrologic events in rivers. Journal of Hydrology 111 (1-4):89-106.

Zuecco, G., D. Penna, M. Borga, and H. J. van Meerveld. 2016. A versatile index to characterize hysteresis between hydrological variables at the runoff event timescale. Hydrological Processes 30 (9):1449-1466. 


\section{Appendix A. Literature review table}

\begin{tabular}{|c|c|c|c|c|}
\hline & Study Area & & Variables & \\
\hline Authors & & Landscape Factors & SExamined & Main Findings \\
\hline $\begin{array}{l}\text { Foster } \\
1978\end{array}$ & $\begin{array}{l}1.6 \text { sqkm } \\
\text { agricultural } \\
\text { watershed }\end{array}$ & $\begin{array}{l}\text { Agriculture land } \\
\text { use, geology }\end{array}$ & $\begin{array}{l}\text { Solute } \\
\text { concentration, } \\
\text { discharge }\end{array}$ & $\begin{array}{l}\text { Solute exhibited hysteretic responses during } \\
\text { storms and are seasonally dependent }\end{array}$ \\
\hline $\begin{array}{l}\text { Walling } \\
\text { and Webb } \\
1980\end{array}$ & $\begin{array}{l}601 \mathrm{sqkm} \\
\text { heterogenous } \\
\text { basin }\end{array}$ & $\begin{array}{l}\text { Geology, rural area, } \\
\text { agricultural land } \\
\text { cover }\end{array}$ & $\begin{array}{l}\text { Dissolved } \\
\text { solids, specific } \\
\text { conductance, } \\
\text { discharge }\end{array}$ & $\begin{array}{l}\text { Hysteretic and lag effects in both } \\
\text { hydrography and chemograph, aggregation } \\
\text { and spatial variation of solute behavior } \\
\text { upstream is important in predicting runoff } \\
\text { response }\end{array}$ \\
\hline $\begin{array}{l}\text { Moog and } \\
\text { Whiting } \\
1998\end{array}$ & Central Idaho & $\begin{array}{l}\text { Basin morphology, } \\
\text { geology }\end{array}$ & $\begin{array}{l}\text { Discharge, bed } \\
\text { load, } \\
\text { suspended } \\
\text { sediment }\end{array}$ & $\begin{array}{l}\text { Annual clockwise hysteresis in bed load with } \\
\text { varying channel topography, supply of } \\
\text { sediment diminishes as flow discharge reach } \\
\text { a low threshold value }\end{array}$ \\
\hline $\begin{array}{l}\text { Asselman } \\
1999\end{array}$ & $\begin{array}{l}165000 \text { sqkm } \\
\text { River Rhine }\end{array}$ & Sediment storage & $\begin{array}{l}\text { Discharge, } \\
\text { suspended } \\
\text { sediment } \\
\text { concentration }\end{array}$ & $\begin{array}{l}\text { Sediment transport in winter is related to } \\
\text { energy conditions and temporary storage of } \\
\text { sediment in during low flow in summer. } \\
\text { "Supply-based" model able to predicts } \\
\text { hysteresis effects on sediment exhaustion }\end{array}$ \\
\hline $\begin{array}{l}\text { Brasington } \\
\text { and Keith } \\
2000\end{array}$ & $\begin{array}{l}\text { Nepal Middle } \\
\text { Hills }\end{array}$ & $\begin{array}{l}\text { Land use, geology, } \\
\text { development }\end{array}$ & $\begin{array}{l}\text { Water, solute } \\
\text { and sediment } \\
\text { fluxes }\end{array}$ & $\begin{array}{l}\text { Using turbidity data to estimate suspended } \\
\text { sediment response can be highly episodic, } \\
\text { seasonal trends and sediment exhaustion can } \\
\text { strongly influence hysteresis forms }\end{array}$ \\
\hline $\begin{array}{l}\text { Lawler et } \\
\text { al } 2006\end{array}$ & $\begin{array}{l}\text { Upper River } \\
\text { Tame, UK }\end{array}$ & $\begin{array}{l}\text { Point source } \\
\text { discharge, land use, } \\
\text { development, rural } \\
\text { vs urban land cover }\end{array}$ & $\begin{array}{l}\text { Turbidity, DO, } \\
\mathrm{pH} \text {, ammonia, } \\
\text { temperature, } \\
\text { discharge }\end{array}$ & $\begin{array}{l}\text { Anticlockwise hysteresis for discharge- } \\
\text { turbidity relations found in rural channels. } \\
\text { Supply of suspended sediment is sustained in } \\
\text { urban settings }\end{array}$ \\
\hline $\begin{array}{l}\text { Kroger et } \\
\text { al } 2013\end{array}$ & $\begin{array}{l}\text { Wolf-Broad } \\
\text { oxbow lake }\end{array}$ & $\begin{array}{l}\text { Landscape } \\
\text { management, } \\
\text { topography, land } \\
\text { cover, soil type }\end{array}$ & $\begin{array}{l}\text { Suspended } \\
\text { sediment } \\
\text { concentration, } \\
\text { discharge, } \\
\text { turbidity }\end{array}$ & $\begin{array}{l}\text { Increased hydraulic resident time and } \\
\text { increase volume of sediment settling } \\
\text { improved downstream water quality, } \\
\text { turbidity and sediment output varied spatially } \\
\text { and temporally }\end{array}$ \\
\hline $\begin{array}{l}\text { Tuset et al } \\
2016\end{array}$ & $\begin{array}{l}\text { Mediterranean } \\
\text { mountain } \\
\text { watershed } 224 \\
\mathrm{~km}^{2}\end{array}$ & $\begin{array}{l}\text { Geology, land } \\
\text { cover, soil type }\end{array}$ & $\begin{array}{l}\text { Precipitation, } \\
\text { runoff, }\end{array}$ & $\begin{array}{l}\text { Maximum suspended sediment positively } \\
\text { correlated with flood magnitude, total } \\
\text { suspended sediment load can be predicted by } \\
\text { rainfall and runoff variables, seasonality } \\
\text { changes sediment transport patterns }\end{array}$ \\
\hline $\begin{array}{l}\text { Vaughan } \\
2017\end{array}$ & $\begin{array}{l}\text { Upper } \\
\text { Mississippi } \\
\text { River Basin }\end{array}$ & $\begin{array}{l}\text { Geology, } \\
\text { geomorphology, } \\
\text { soil, land use, near } \\
\text { channel conditions, } \\
\text { land cover }\end{array}$ & $\begin{array}{l}\text { Total } \\
\text { suspended } \\
\text { solids, } \\
\text { discharge }\end{array}$ & $\begin{array}{l}\text { Steepness is strongly related to near-channel } \\
\text { morphology, steeper channel banks are } \\
\text { highly sensitive to discharge changes, } \\
\text { hysteresis is positively associated with higher } \\
\text { near-channel local relief }\end{array}$ \\
\hline
\end{tabular}

